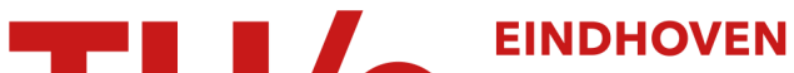 \\ UNIVERSITY OF \\ TECHNOLOGY
}

\section{Photoconductive switching of a high-voltage spark gap}

Citation for published version (APA):

Brussaard, G. J. H., \& Hendriks, J. (2005). Photoconductive switching of a high-voltage spark gap. Applied Physics Letters, 86(8), 081503-1/3. [081503]. https://doi.org/10.1063/1.1866227

DOI:

10.1063/1.1866227

Document status and date:

Published: 01/01/2005

\section{Document Version:}

Publisher's PDF, also known as Version of Record (includes final page, issue and volume numbers)

\section{Please check the document version of this publication:}

- A submitted manuscript is the version of the article upon submission and before peer-review. There can be important differences between the submitted version and the official published version of record. People interested in the research are advised to contact the author for the final version of the publication, or visit the $\mathrm{DOI}$ to the publisher's website.

- The final author version and the galley proof are versions of the publication after peer review.

- The final published version features the final layout of the paper including the volume, issue and page numbers.

Link to publication

\section{General rights}

Copyright and moral rights for the publications made accessible in the public portal are retained by the authors and/or other copyright owners and it is a condition of accessing publications that users recognise and abide by the legal requirements associated with these rights.

- Users may download and print one copy of any publication from the public portal for the purpose of private study or research.

- You may not further distribute the material or use it for any profit-making activity or commercial gain

- You may freely distribute the URL identifying the publication in the public portal.

If the publication is distributed under the terms of Article $25 \mathrm{fa}$ of the Dutch Copyright Act, indicated by the "Taverne" license above, please follow below link for the End User Agreement:

www.tue.nl/taverne

Take down policy

If you believe that this document breaches copyright please contact us at:

openaccess@tue.nl

providing details and we will investigate your claim. 


\title{
Photoconductive switching of a high-voltage spark gap
}

\author{
G. J. H. Brussaard ${ }^{\text {a) }}$ and J. Hendriks \\ Center for Plasma Physics and Radiation Technology, Eindhoven University of Technology, P.O. Box 513, \\ 5600 MB Eindhoven, The Netherlands
}

(Received 20 September 2004; accepted 21 December 2004; published online 17 February 2005)

\begin{abstract}
We have demonstrated photoconductive switching of a gas-filled spark gap. A femtosecond Ti:sapphire laser was focused in a $1 \mathrm{~mm}$ spark gap biased at $4.5 \mathrm{kV}$. There is a clear transition between triggered operation, when only part of the path between the electrodes is ionized, and photoconductive switching, when the entire length of the gap is ionized directly by the laser. The measured standard deviation of the time fluctuations between the rising edge of the transmitted electrical pulse and the laser was less than 15 ps. (C) 2005 American Institute of Physics. [DOI: $10.1063 / 1.1866227]$
\end{abstract}

High-voltage applications (above $\sim 1 \mathrm{kV}$ ) that require accurate timing use laser triggering of gas-filled spark gaps to switch electrical pulses. In these spark gaps, a laser is focused between the electrodes or on one of the electrodes to create a small amount of ionization. The free electrons are accelerated in the gap and cause additional ionization (avalanche, streamer formation) and, eventually, a conducting (arc) channel is formed between the electrodes. ${ }^{1,2}$ Typical rise time and jitter of these switches in the $1-100 \mathrm{kV}$ range is of the order of $100 \mathrm{~s}$ of picoseconds. A recent improvement in this field was reported by Luther et al. ${ }^{3}$ who used a femtosecond Ti:sapphire laser to trigger the breakdown of a pressurized high-voltage air spark gap at $10 \mathrm{kV}$ and obtained jitter as low as 35 ps. A different technique, namely laserdriven photoconductive switching, has been used to produce pulses with (sub-)picosecond risetime, albeit at lower voltages (below $\sim 1 \mathrm{kV}$ ). In these switches, a high-resistivity semiconductor separates two electrodes or transmission lines. When a laser pulse illuminates the semiconductor, free carriers are generated and the semiconductor becomes conducting. The switch is closed if a full path between the electrodes is illuminated with sufficient laser intensity. Motet et $\mathrm{al}^{4}{ }^{4}$ have reported the generation of $825 \mathrm{~V}$ pulses with a rise time of 1.4 ps using low-temperature grown GaAs, illuminated by a $150 \mathrm{fs}, 2 \mu \mathrm{J}$ dye laser at $620 \mathrm{~nm}$ wavelength. The basic difference between laser triggering of a spark gap and photoconductive switching is that in the former only part of the path between the electrodes is ionized, whereas in the latter a complete conducting path is created directly by the laser. In this letter we report the results from a switch designed to combine the benefits of both techniques: The highvoltage, high current capabilities of a gas filled spark gap and the fast response of a photoconductive switch.

With today's high power femtosecond lasers it is possible to ionize a complete path between the electrodes of a gas-filled gap by tunneling ionization. ${ }^{5,6}$ If the intensity of the laser is high enough (around $10^{14} \mathrm{~W} / \mathrm{cm}^{2}$ ) along the whole path between the electrodes, plasma fills the entire gap and the switch is effectively closed on the time scale of a few femtoseconds. To demonstrate this principle, a spark gap was constructed, shown in Fig. 1, integrated in a coaxial transmission line. The inner conductor of the transmission line

${ }^{a}$ Author to whom correspondence should be addressed; electronic mail: g.j.h.brussaard@tue.nl has a diameter of $6 \mathrm{~mm}$ and the inner diameter of the outer conductor is $15 \mathrm{~mm}$ ( $55 \Omega$ impedance). The transmission line is interrupted by a gap of $1 \mathrm{~mm}$. The laser is focused in the gap using two cylindrical lenses, to ionize a slab of plasma between the electrodes. The gap is filled with air at $1 \mathrm{~atm}$. Our Ti:sapphire laser system produces pulses of approximately $200 \mathrm{fs}$ at $800 \mathrm{~nm}$ with energy up to $35 \mathrm{~mJ}$ at a repetition rate of $10 \mathrm{~Hz}$. The incoming beam has a diameter of 7 $\mathrm{mm}$ (full width at half maximum). The two cylindrical lenses have focal distances of 150 and $200 \mathrm{~mm}$ and are positioned at 150 and $186 \mathrm{~mm}$ from the center of the gap, respectively. This produces a line focus between the electrodes of the spark gap (in the focal plane of the $150 \mathrm{~mm}$ lens) with a width of $20 \mu \mathrm{m}$ and a length, along the axis of the spark gap of $0.5 \mathrm{~mm}$ (both dimensions are full width at half maximum of the intensity). At maximum laser power, the intensity along the axis of the spark gap varies from $10^{15} \mathrm{~W} / \mathrm{cm}^{2}$ at the center to $10^{13} \mathrm{~W} / \mathrm{cm}^{2}$ at the electrode surfaces, comparable to the intensities used by Luther et $a l^{3}$ and above the threshold for tunnel ionization (Keldysh parameter ${ }^{7} \quad \gamma<1$ ) along $80 \%$ of the path between the electrodes. A slit is used at the entry port of the spark gap to prevent the edges of the laser pulse from hitting the electrodes.

The 30-cm-long transmission line at the primary side of the switch is charged to a maximum of $5 \mathrm{kV}$ (the selfbreakdown voltage of the gap). The pulse in the secondary line is measured capacitively through a small gap in the transmission line and the signal is integrated digitally by the oscilloscope (HP Infinium, 1.5 GHz). The absolute value of the measured output pulses is an estimate based on the ca-

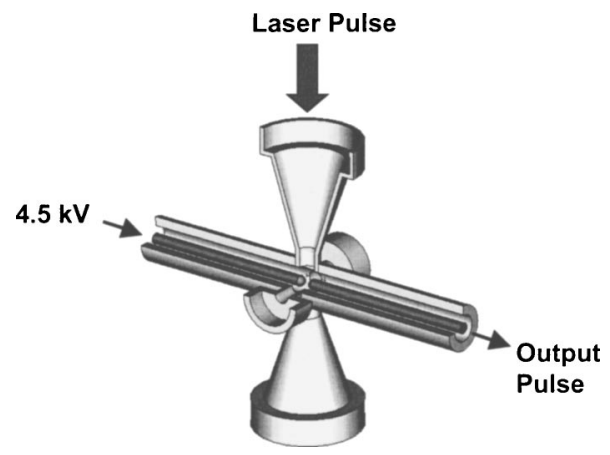

FIG. 1. Cut view of the switch. 


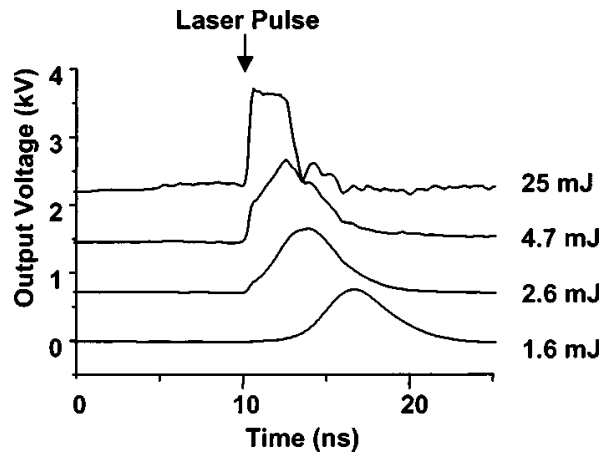

FIG. 2. Pulses switched at different laser energy: The measurements at different energy have been offset for clarity. The equivalent arrival time of the laser pulse in the gap has been indicated.

pacitance measured at $500 \mathrm{MHz}(\approx 13 \mathrm{fF})$ and losses in the cables $(\approx 10 \%$ at $1 \mathrm{GHz})$.

The results of the switching experiments are shown in Fig. 2 at a charging voltage of the primary line of $4.5 \mathrm{kV}$ (90\% of the self-breakdown voltage). At low energy (around $1 \mathrm{~mJ}$ ) only a small amount of plasma is produced, in the center of the gap. In this case the switch is triggered in the classical sense. The free electrons initiate an avalanche which eventually causes breakdown of the gap and closes the switch. At higher energy (above approximately $2 \mathrm{~mJ}$ ) a small step appears just after the laser pulse. A narrow plasma channel is created by the laser pulse connecting the electrodes. The stages of avalanche and/or streamer formation are omitted, but the impedance of the plasma is high compared to the transmission lines. As the current starts to run, an arc channel starts to develop, gradually reducing the impedance of the plasma. The same effect, but more pronounced, is visible at even higher energy (5-20 mJ). In this case, a drop off in the transmitted voltage pulse is visible, $2 \mathrm{~ns}$ after the initial step. This can be explained by the fact that the closing of the switch causes a voltage drop in the primary transmission line. This wave front travels backwards through the primary transmission line and reflects at the input resistance. The result is the observed decrease in voltage $2 \mathrm{~ns}$, or twice the length of the primary line, after the closing of the switch. True photoconductive switching of the gap is shown in the upper graph of Fig. 2. At laser pulse energies above approximately $20 \mathrm{~mJ}$, the impedance of the initial plasma is low enough to transmit the entire pulse without significant loss. A square pulse is observed in the secondary line with a duration of $2 \mathrm{~ns}$, twice the length of the primary line. The height of the step at the beginning of the transmitted electrical pulse

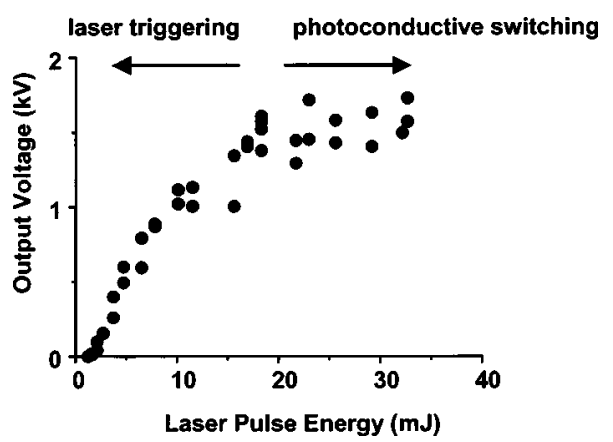

FIG. 3. Amplitude of the front edge of the switched pulse as a function of

${ }^{2}$ M. J. Kushner, R. D. Milroy, and W. D. Kimura, J. Appl. Phys. 58, 2988
laser pulse energy.
Downloaded 24 Oct 2007 to 131.155.108.71. Redistribution subject to AlP license or copyright, see http://apl.aip.org/apl/copyright.jsp

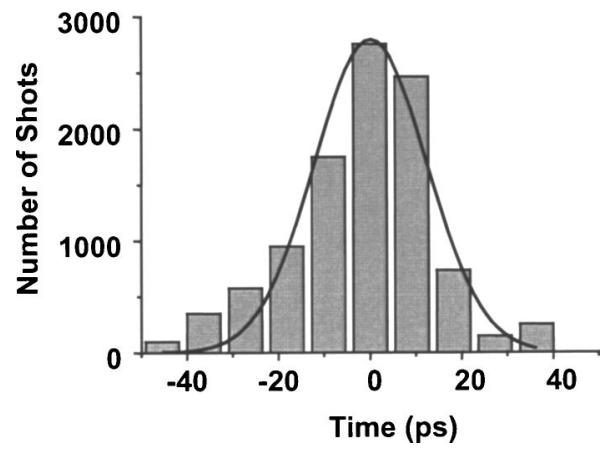

FIG. 4. Time variation of the front edge of the high-voltage pulse with respect to the laser pulse. The line is a Gaussian fit to the data, $\sigma=12 \mathrm{ps}$.

is plotted as a function of laser energy in Fig. 3. At low energy, the initial step is only a fraction of the charging voltage. At higher laser energy, in the photoconductive switching regime, the maximum amplitude of the pulse is reached in the first step. Increasing the laser power further has little effect on the output pulse, which is now completely determined by the length of the primary transmission line and the charging voltage. We have measured similar pulses at charging voltages as low as $10 \%$ of the self-breakdown voltage.

The measured rise time of the square pulses (above 20 $\mathrm{mJ}$ ) is $100 \mathrm{ps}$, which is limited by the oscilloscope (1.5 $\mathrm{GHz}$ ). It is expected that the actual rise time of the pulse is much shorter, of the order of the transit time of the pulse through the gap, which is only $3 \mathrm{ps}$, but this is presently beyond our measuring capabilities. We have attempted to measure the delay between the arrival of the laser pulse in the gap and the onset of transmitted pulse. After accounting for the different cable lengths, the measured delay between the laser pulse and the rising edge of the transmitted pulse was less than 200 ps. The corresponding time of arrival of the laser pulse is indicated in Fig. 2. The jitter between the laser pulse and the rising edge of the transmitted pulse was measured at $4.5 \mathrm{kV}$ charging voltage and $25 \mathrm{~mJ}$ laser pulse energy. The histogram in Fig. 4 shows the variation of the rising edge as it crosses a fixed level, approximately half the amplitude of the transmitted pulse. Over a period of $15 \mathrm{~min}$, at a repetition rate of $10 \mathrm{~Hz}$, the measured jitter $(\sigma)$ is less than 15 ps. The accuracy of this measurement is determined by the oscilloscope. The limited measurable rise time of 100 ps means that variations in the amplitude of the transmitted pulse are translated directly into a variation in the time at which the rising edge passes through the preset level. A variation of $10 \%$ in the output voltage results in a contribution of $10 \mathrm{ps}$ to the measured jitter.

In conclusion, we report the demonstration of a photoconductively switched gas-filled spark gap. There is a clear transition between triggered and photoconductive operation of the switch. In the photoconductive mode, this technique enables switching far below the self-breakdown voltage, which greatly extends the range of voltages that can be controlled by a single switch.

The authors gratefully acknowledge the assistance of E. Rietman, A. Kemper, and H. van Doorn. The research of Dr. Brussaard has been made possible by a fellowship of the Royal Netherlands Academy of Arts and Sciences.

${ }^{1}$ R. A. Dougal and P. F. Williams, J. Phys. D 17, 903 (1984).

${ }^{2}$ M. J. Kushner, R. D. Milroy, and W. D. Kimura, J. Appl. Phys. 58, 2988

AIP license or copyright, see http://apl.aip.org/apl/copyright.jsp
A 
(1985).

${ }^{3}$ B. M. Luther, L. Furfaro, A. Klix, and J. J. Rocca, Appl. Phys. Lett. 79, 3248 (2001).

${ }^{4}$ T. Motet, J. Nees, S. Williamson, and G. Mourou, Appl. Phys. Lett. 59, 1455 (1991).
${ }^{5}$ S. Augst, D. Strickland, D. D. Meyerhofer, S. L. Chin, and J. H. Eberly, Phys. Rev. Lett. 63, 2212 (1989).

${ }^{6}$ C. Guo, M. Li, J. P. Nibarger, and G. N. Gibson, Phys. Rev. A 58, R4271 (1998).

${ }^{7}$ L. V. Keldysh, Sov. Phys. JETP 20, 1307 (1965). 